\title{
Character Association and Path Analysis in Diverse Genotypes of Pea (Pisum sativum L.)
}

\author{
Shalini Singh ${ }^{1}$, B. Singh ${ }^{1}$, V. Rakesh Sharma ${ }^{2}$, Vinay Verma ${ }^{1}$ and Mukesh Kumar ${ }^{1}$ \\ ${ }^{1}$ Department of Horticulture, Sardar Vallabhbhai Patel University of Agriculture and \\ Technology, Meerut - 250110 (U.P.), India \\ ${ }^{2}$ CSIR- NBRI, Rana Pratap Marg, Lucknow -226 001 (U.P), India \\ *Corresponding author
}

\begin{tabular}{|c|c|}
\hline & A B S T R A C T \\
\hline $\begin{array}{l}\text { Ke y w o r d s } \\
\text { Genotypes of pea, } \\
\text { Pisum sativum L. } \\
\text { Path analysis }\end{array}$ & \multirow{3}{*}{$\begin{array}{l}\text { Fifty-five pea (Pisum sativum L.) genotypes were evaluated using eleven morphological } \\
\text { traits to assess the interrelationship among yield and yield-related attributes and their direct } \\
\text { and indirect effects on seed yield. Based on the correlation coefficient analysis, seed yield } \\
\text { per plant showed positive and significant association with green pod yield per plant, shell } \\
\text { weight per plant, number of pods per plant and length of pod both at genotypic and } \\
\text { phenotypic levels. Path coefficient analysis revealed that direct positive effect on seed } \\
\text { yield per plant was exhibited by green pod yield per plant, number of first fruiting node, } \\
\text { length of pod, days to } 50 \% \text { flowering and plant height. Hence, from correlation and path } \\
\text { analysis it can be inferred that green pod yield per plant and pod length revealed } \\
\text { significant and positive correlation and direct positive effect on seed yield and these traits } \\
\text { shall be used as key indices towards the direct selection of genotypes for the successful } \\
\text { breeding programme for yield improvement of pea germplasm. }\end{array}$} \\
\hline Article Info & \\
\hline $\begin{array}{l}\text { Accepted: } \\
\text { 07 January } 2019 \\
\text { Available Online: } \\
\text { 10 February } 2019\end{array}$ & \\
\hline
\end{tabular}

\section{Introduction}

Pea (Pisum sativum L.) also called as "Matar" is an important legume vegetable for temperate and sub-tropical regions of the world and its center of origin is Mediterranean region of Southern Europe and Western Asia. It is an important crop because of its diversity of utilization and extensive production areas (Boros and Wawer, 2009). It is grown for its fresh green seeds, edible pods, dried seeds and foliage (Duke, 1981). Being number one of the processed vegetables, it can be used for off-season consumption in its fresh, canned frozen or dehydrated forms (Santalla et al., 2001). It is a rich source of health benefiting Phyto-nutrients, minerals, vitamins and antioxidants and is known for its superior quality protein like high levels of lysine making it an appropriate dietary complement to cereals (Gul et al., 2006; Dhama et al., 2010). It also plays an important role in nitrogen fixation. Short duration and early varieties of pea have the potential to provide premium returns to the farmers as they can fetch a better price and can be used for multi-cropping (Anant et al., 2006). 
Pea occupies 5.43 lakh hectare area in India with production of 54.32 lakh tons (NHB, 2017-18) and shares 21 percent production of the world. Uttar Pradesh is a major field pea producing state in India producing about $60 \%$ of the country's produce. The productivity of pea is quite low to fit the required demand and this may be mainly due to lack of high yielding varieties and resistance to biotic and abiotic stress (Kumar et al., 2015). To meet the current demand, there is an urgent need of germplasm evaluation for genetic improvement of pea germplasm to develop desired high yielding genotypes. Yield improvement cannot be solely achieved through direct selection because yield is a complex character, which is dependent on various yield-related traits and environmental conditions. The efficiency of selection in any breeding programme is enhanced with the knowledge of the association of yield components and their relative contribution shown by path analysis. It guides the breeder to realize the actual yield components and furnish an effective basis of phenotypic selection. Correlation analysis helps in the evaluation of relationship existing between yield and its components.

Determination of the traits having the greatest influence on yield can be done through path coefficient analysis which permits the partitioning of correlation coefficients into direct and indirect effects, giving the relative importance of each of the causal factors. This knowledge of path coefficient is a decision support tool that helps researchers to determine the contribution of each variable to the response variable and each variable via other variables to that response variable (Akinnola, 2012). The present study was undertaken to determine the inter-relationship among the components and the direct and indirect influences of each of the component characters towards the pea yield in order to predict an appropriate plant type to be used as base material for further pea breeding programme.

\section{Materials and Methods}

A total of fifty-five genotypes of garden pea were evaluated using eleven morphological traits at Horticultural Research Centre, SVPUA\&T, Meerut during Rabi season, 2015. The details of the genotypes along with their availability of sources are given in table 1. The experiment was laid out in RBD with three replications. All the genotypes selected for the research were planted in row-to-row and plant-to-plant spacing of $60 \mathrm{~cm}$ and 10 $\mathrm{cm}$, respectively. All the recommended horticultural practices and plant protection measures were followed uniformly from time to time to raise a healthy crop. After eliminating the border and unhealthy plants five plants were randomly selected in each genotype per replication for observations. Observations were recorded for eleven morphological traits viz., days to $50 \%$ flowering, plant height $(\mathrm{cm})$, number of first fruiting node, length of first fruiting node $(\mathrm{cm})$, number of pods per plant, length of pod $(\mathrm{cm})$, width of pod $(\mathrm{cm})$, number of seeds per pod, green pod yield per plant $(\mathrm{g})$, shell weight per plant $(\mathrm{g})$ and seed yield per plant (g). The mean values were subjected to statistical analysis to work out phenotypic and genotypic correlation coefficient (Johnson et al., 1955). Path coefficient analysis was performed according to Dewey and Lu (1959) to compute the direct and indirect effects of the traits on the total yield per plant.

\section{Results and Discussion}

A total of fifty-five pea genotypes were evaluated using eleven morphological traits. Based on analysis of variance, all the eleven characters studied showed significant differences, indicating the presence of sufficient variability among the genotypes. 
Since, yield is a complex and polygenic character, the genetic improvement of yield can merely achieve through indirect selection of other associated character. Thus, character association study was conducted in order to know how various characters are correlated with yield and intercorrelated among each other. Character correlations were made at both genotypic and phenotypic levels as shown in table 2. In general, the magnitude of genotypic correlation coefficient was higher than their corresponding phenotypic correlation coefficient. This indicated a strong inherent relationship in different pair of characters dependent on environment influence which modifies the expression of genotype, thus altering the phenotypic expression (Nandpuri et al., 1973). These results are similar to the findings of Nawab et al., (2009) and Pal and Singh (2012).

The correlation studies revealed that seed yield per plant showed significant and positive correlation with green pod yield per plant, shell weight per plant, number of pods per plant and length of pod both at genotypic and phenotypic level, which suggested the possibilities of improving seed yield by simultaneous improvement of these traits. Similar trend was reported by Yadav et al., (2010); Devi et al., (2010) for green pod yield per plant, number of pods per plant and pod length; Tiwari and Lavanya (2012) and Kumar et al., (2014) for pod length. Negative correlation was observed at genotypic and phenotypic level for plant height, length of first fruiting node and days to $50 \%$ flowering, indicating that these characters shall be taken into consideration for the earliness of the crop.

In the inter correlation among the characters, green pod yield per plant exhibited positive significant association with number of pods per plant and length of pod at both genotypic and phenotypic level. The results are in close harmony with the findings of Pal and Singh (2012); Karnwal et al., (2013) and Kumar et al., (2015). In addition, plant height showed positive and significant correlation with days to $50 \%$ flowering at genotypic and phenotypic level. Therefore, knowledge on the inter correlation association of the traits may be considered as the most reliable selections indices for effective improvement in pea.

The genotypic and phenotypic correlations were further analyzed by path coefficient technique because correlation coefficients are the indication of simple association between variables. In addition, knowledge on presence of association among component characters reveals that some of them may serve as indicator of yield. This involves partitioning of the correlations into direct and indirect effects via alternative characters or pathways. In the present investigation, path coefficient analysis revealed that green pod yield per plant exhibited very high direct positive effect on seed yield per plant both at genotypic and phenotypic level. In addition, significant positive direct effect on seed yield per plant was also observed by number of first fruiting node, length of pod, days to $50 \%$ flowering and plant height (Table 3). Therefore, direct selection of these traits might bring an overall improvement in the crop yield as these characters played an important role in increasing seed yield per plant. These results were in agreement with the findings of Rai et al., (2006) for days to $50 \%$ flowering and plant height; Sharma et al., (2007) for plant height and length of pod; Singh et al., (2011) for plant height; Kumar et al., (2013); for pod length and days to $50 \%$ flowering and Siddika et al., (2013) for days to $50 \%$ flowering. However, in negative direction significant direct effect on seed yield per plant was exhibited by shell weight per plant, length of first fruiting node, number of seeds per pod, width of pod and number of pods per plant. The high indirect effect also showed that most 
of the characters influenced the seed yield through number of pods per plant and number of seeds per pod. These results are in preponderance with the findings of Rasaei et al., (2011).

Table.1 List of garden pea genotypes evaluated for the present study

\begin{tabular}{|c|c|c|c|c|c|}
\hline $\mathbf{S} / \mathbf{N}$ & $\begin{array}{l}\text { Genotypes } \\
\text { Names }\end{array}$ & $\begin{array}{l}\text { Source of } \\
\text { collection }\end{array}$ & $\mathbf{S} / \mathbf{N}$ & $\begin{array}{l}\text { Genotypes } \\
\text { Names }\end{array}$ & Source of collection \\
\hline 1. & VRP-3 & I.I.V.R., Varanasi & 31. & VRP-174 & I.I.V.R., Varanasi \\
\hline 2. & VRP-13 & I.I.V.R., Varanasi & 32. & VRP-95 & I.I.V.R., Varanasi \\
\hline 3. & VRP-26 & I.I.V.R., Varanasi & 33. & VRP-49 & I.I.V.R., Varanasi \\
\hline 4. & VRP-194 & I.I.V.R., Varanasi & 34. & VRP-276 & I.I.V.R., Varanasi \\
\hline 5. & VRP-222 & I.I.V.R., Varanasi & 35. & VRP-82 & I.I.V.R., Varanasi \\
\hline 6. & VRP-375 & I.I.V.R., Varanasi & 36 & VRP-145 & I.I.V.R., Varanasi \\
\hline 7. & VRP-324 & I.I.V.R., Varanasi & 37. & VRP-343 & I.I.V.R., Varanasi \\
\hline 8. & VRP-115 & I.I.V.R., Varanasi & 38. & VRP-131 & I.I.V.R., Varanasi \\
\hline 9. & VRP-69 & I.I.V.R., Varanasi & 39. & VRP-248 & I.I.V.R., Varanasi \\
\hline 10. & VRP-313 & I.I.V.R., Varanasi & 40. & VRP-64 & I.I.V.R., Varanasi \\
\hline 11. & VRP-311 & I.I.V.R., Varanasi & 41. & VRPM-15 & I.I.V.R., Varanasi \\
\hline 12. & VRP-73 & I.I.V.R., Varanasi & 42 & VP-233 & I.I.V.R., Varanasi \\
\hline 13. & VRP-228 & I.I.V.R., Varanasi & 43. & EC-97280 & N.B.P.G.R., New Delhi \\
\hline 14. & VRP-321 & I.I.V.R., Varanasi & 44. & EC-8372 & N.B.P.G.R., New Delhi \\
\hline 15. & VRP-320 & I.I.V.R., Varanasi & 45 & EC-8724 & N.B.P.G.R., New Delhi \\
\hline 16. & VRP-355 & I.I.V.R., Varanasi & 46. & EC-71944 & N.B.P.G.R., New Delhi \\
\hline 17. & VRP-16 & I.I.V.R., Varanasi & 47. & MO-23 & I.I.V.R., Varanasi \\
\hline 18. & VRP-22 & I.I.V.R., Varanasi & 48. & MO-19 & I.I.V.R., Varanasi \\
\hline 19. & VRP-122 & I.I.V.R., Varanasi & 49. & KS-228 & I.I.V.R., Varanasi \\
\hline 20. & VRP-383 & I.I.V.R., Varanasi & 50. & DPP-94/8-06 & I.I.V.R., Varanasi \\
\hline 21. & VRP-284 & I.I.V.R., Varanasi & 51. & UDAY & I.I.V.R., Varanasi \\
\hline 22. & VRP-65 & I.I.V.R., Varanasi & 52 & MUKTI & I.I.V.R., Varanasi \\
\hline 23. & VRP-223 & I.I.V.R., Varanasi & 53. & SHAKTI & I.I.V.R., Varanasi \\
\hline 24. & VRP-402 & I.I.V.R., Varanasi & 54. & SAMRIDHI & I.I.V.R., Varanasi \\
\hline 25. & VRP-382 & I.I.V.R., Varanasi & 55. & NANDINI & I.I.V.R., Varanasi \\
\hline 26. & VRP-176 & I.I.V.R., Varanasi & & & \\
\hline 27. & VRP-273 & I.I.V.R., Varanasi & & & \\
\hline 28. & VRP-327 & I.I.V.R., Varanasi & & & \\
\hline 29. & VRP-107 & I.I.V.R., Varanasi & & & \\
\hline 30. & VRP-156 & I.I.V.R., Varanasi & & & \\
\hline
\end{tabular}


Table.2 Estimates of genotypic and phenotypic correlation co-efficient between different characters of pea

\begin{tabular}{|c|c|c|c|c|c|c|c|c|c|c|c|c|}
\hline & & X1 & $\mathrm{X} 2$ & X3 & X4 & X5 & X6 & $\mathbf{X} 7$ & X8 & X9 & X10 & X11 \\
\hline \multirow[t]{2}{*}{$\mathrm{X} 1$} & $\mathrm{G}$ & 1.000 & $0.392 * *$ & 0.081 & 0.115 & 0.092 & $-0.368 * *$ & $-0.250 * *$ & $0.162^{*}$ & -0.150 & -0.068 & $-0.204 * *$ \\
\hline & $\mathrm{P}$ & 1.000 & $0.377 * *$ & 0.085 & 0.109 & 0.090 & $-0.355 * *$ & $-0.233 * *$ & $0.157^{*}$ & -0.145 & -0.069 & $-0.192 *$ \\
\hline \multirow[t]{2}{*}{$\mathrm{X} 2$} & $\mathrm{G}$ & & & 0.068 & $0.526^{* *}$ & -0.071 & $-0.246 * *$ & -0.131 & $0.261 * *$ & $-0.256^{* *}$ & $-0.203 * *$ & $-0.293 * *$ \\
\hline & $\mathrm{P}$ & & & 0.069 & $0.508^{* *}$ & -0.070 & $-0.243 * *$ & -0.125 & $0.256^{* *}$ & $-0.251 * *$ & $-0.200^{*}$ & $-0.287 * *$ \\
\hline \multirow[t]{2}{*}{$\mathbf{X} 3$} & G & & & & $0.703 * *$ & 0.018 & -0.129 & -0.001 & 0.133 & -0.049 & 0.011 & -0.117 \\
\hline & $\mathrm{P}$ & & & & $0.686^{* *}$ & 0.015 & -0.124 & -0.017 & 0.130 & -0.046 & 0.008 & -0.105 \\
\hline \multirow[t]{2}{*}{$\mathrm{X} 4$} & $\mathrm{G}$ & & & & & -0.069 & -0.078 & -0.070 & $0.162^{*}$ & -0.143 & -0.082 & $-0.214 * *$ \\
\hline & $\mathrm{P}$ & & & & & -0.070 & -0.075 & -0.067 & 0.150 & -0.136 & -0.079 & $-0.205 * *$ \\
\hline \multirow[t]{2}{*}{ X5 } & $\mathrm{G}$ & & & & & & -0.085 & $-0.179 *$ & -0.149 & $0.835^{* *}$ & $0.859 * *$ & $0.745^{* *}$ \\
\hline & $\mathrm{P}$ & & & & & & -0.083 & $-0.166^{*}$ & -0.147 & $0.832 * *$ & $0.851 * *$ & $0.737 * *$ \\
\hline \multirow[t]{2}{*}{ X6 } & $\mathrm{G}$ & & & & & & & $0.311 * *$ & $0.245^{* *}$ & $0.343^{* *}$ & $0.266^{* *}$ & $0.394 * *$ \\
\hline & $\mathrm{P}$ & & & & & & & $0.284 * *$ & $0.236^{* *}$ & $0.336^{* *}$ & $0.258^{* *}$ & $0.383 * *$ \\
\hline \multirow[t]{2}{*}{ X7 } & $\mathrm{G}$ & & & & & & & & -0.004 & -0.008 & -0.043 & 0.026 \\
\hline & $\mathrm{P}$ & & & & & & & & -0.007 & -0.011 & -0.042 & 0.020 \\
\hline \multirow[t]{2}{*}{ X8 } & $\mathrm{G}$ & & & & & & & & & 0.002 & -0.111 & 0.100 \\
\hline & $\mathrm{P}$ & & & & & & & & & 0.000 & -0.105 & 0.095 \\
\hline \multirow[t]{2}{*}{ X9 } & $\mathrm{G}$ & & & & & & & & & & $0.958 * *$ & $0.961 * *$ \\
\hline & $\mathrm{P}$ & & & & & & & & & & $0.948 * *$ & $0.955 * *$ \\
\hline \multirow[t]{2}{*}{ X10 } & $\mathrm{G}$ & & & & & & & & & & & $0.843 * *$ \\
\hline & $\mathrm{P}$ & & & & & & & & & & & $0.822 * *$ \\
\hline \multirow[t]{2}{*}{ X11 } & $\mathrm{G}$ & & & & & & & & & & & 1.000 \\
\hline & $\mathrm{P}$ & & & & & & & & & & & 1.000 \\
\hline
\end{tabular}


Table.3 Direct and indirect effect of different characters of different traits

\begin{tabular}{|c|c|c|c|c|c|c|c|c|c|c|c|c|}
\hline & & X1 & $\mathrm{X} 2$ & X3 & X4 & X5 & X6 & X7 & X8 & X9 & X10 & X11 \\
\hline \multirow[t]{2}{*}{$\mathrm{X} 1$} & $\mathrm{G}$ & 0.022 & 0.007 & 0.002 & -0.005 & 0.000 & -0.008 & 0.001 & -0.003 & -0.284 & 0.067 & $-0.204 * *$ \\
\hline & $\mathrm{P}$ & 0.006 & -0.0013 & 0.0003 & -0.0043 & -0.0006 & -0.0040 & -0.0001 & 0.0026 & -0.2438 & 0.0530 & $-0.192 *$ \\
\hline \multirow[t]{2}{*}{$\mathrm{X} 2$} & $\mathrm{G}$ & 0.008 & 0.018 & 0.002 & -0.025 & 0.000 & -0.006 & 0.000 & -0.005 & -0.485 & 0.199 & $-0.293^{* *}$ \\
\hline & $\mathrm{P}$ & 0.002 & -0.0035 & 0.0002 & -0.0200 & 0.0005 & -0.0027 & 0.0000 & 0.0042 & -0.4214 & 0.1536 & $-0.287 * *$ \\
\hline \multirow[t]{2}{*}{ X3 } & $\mathrm{G}$ & 0.002 & 0.001 & 0.023 & -0.034 & 0.000 & -0.003 & 0.000 & -0.003 & -0.093 & -0.011 & -0.117 \\
\hline & $\mathrm{P}$ & 0.0005 & -0.0002 & 0.0035 & -0.0270 & -0.0001 & -0.0014 & 0.0000 & 0.0021 & -0.0764 & -0.0064 & -0.105 \\
\hline \multirow[t]{2}{*}{ X4 } & $\mathrm{G}$ & 0.002 & 0.010 & 0.016 & -0.048 & 0.000 & -0.002 & 0.000 & -0.003 & -0.270 & 0.080 & $-0.214 * *$ \\
\hline & $\mathrm{P}$ & 0.0006 & -0.0018 & 0.0024 & -0.0393 & 0.0005 & -0.0008 & 0.0000 & 0.0024 & -0.2291 & 0.0604 & $-0.205 * *$ \\
\hline \multirow[t]{2}{*}{ X5 } & $\mathrm{G}$ & 0.002 & -0.001 & 0.000 & 0.003 & -0.002 & -0.002 & 0.001 & 0.003 & 1.580 & -0.839 & $0.745 * *$ \\
\hline & $\mathrm{P}$ & 0.0005 & 0.0002 & 0.0001 & 0.0028 & -0.0064 & -0.0009 & -0.0001 & -0.0024 & 1.3965 & -0.6534 & 0.737** \\
\hline \multirow[t]{2}{*}{ X6 } & $\mathrm{G}$ & -0.008 & -0.005 & -0.003 & 0.004 & 0.000 & 0.023 & -0.001 & -0.005 & 0.649 & -0.260 & 0.394** \\
\hline & $\mathrm{P}$ & -0.0020 & 0.0008 & -0.0004 & 0.0029 & 0.0005 & 0.0112 & 0.0001 & 0.0038 & 0.5645 & -0.1985 & 0.383** \\
\hline \multirow[t]{2}{*}{ X7 } & $\mathrm{G}$ & -0.005 & -0.002 & 0.000 & 0.003 & 0.000 & 0.007 & -0.003 & 0.000 & -0.016 & 0.042 & 0.026 \\
\hline & $\mathrm{P}$ & -0.0013 & 0.0004 & -0.0001 & 0.0027 & 0.0011 & 0.0032 & 0.0003 & -0.0001 & -0.0187 & 0.0320 & 0.020 \\
\hline \multirow[t]{2}{*}{ X8 } & $\mathrm{G}$ & 0.004 & 0.005 & 0.003 & -0.008 & 0.000 & 0.006 & 0.000 & -0.021 & 0.003 & 0.108 & 0.100 \\
\hline & $\mathrm{P}$ & 0.0009 & -0.0009 & 0.0005 & -0.0059 & 0.0009 & 0.0026 & 0.0000 & 0.0162 & -0.0006 & 0.0809 & 0.095 \\
\hline \multirow[t]{2}{*}{ X9 } & $\mathrm{G}$ & -0.003 & -0.005 & -0.001 & 0.007 & -0.002 & 0.008 & 0.000 & 0.000 & 1.893 & -0.936 & $0.961 * *$ \\
\hline & $\mathrm{P}$ & -0.0008 & 0.0009 & -0.0002 & 0.0054 & -0.0053 & 0.0038 & 0.0000 & 0.0000 & 1.6787 & -0.7277 & $0.955 * *$ \\
\hline \multirow[t]{2}{*}{ X10 } & $\mathrm{G}$ & -0.001 & -0.004 & 0.000 & 0.004 & -0.002 & 0.006 & 0.000 & 0.002 & 1.814 & -0.977 & $0.843 * *$ \\
\hline & $\mathrm{P}$ & -0.0004 & 0.0007 & 0.0000 & 0.0031 & -0.0054 & 0.0029 & 0.0000 & -0.0017 & 1.5906 & -0.7680 & $0.822 * *$ \\
\hline
\end{tabular}

*significant at 5\% level; **significant at 1\% level, X1-Days to 50\% flowering, X2-Plant height(cm), X3-Number of first fruiting node, X4-Length of first fruiting node $(\mathrm{cm})$, X5-Number of pods per plant, X6-Length of pod $(\mathrm{cm})$, X7-Width of pod (cm), X8-Number of seeds per pod, X9-Green pod yield per plant (g), X10-Shell weight per plant (g), X11-R with Seed yield per plant (g) G-Genotypic level, P-Phenotypic Level 
To what extent causal factors accounts for the variability of the dependent factor is determined by residual effect. In this study, the residual effect of path coefficient analysis was 0.0191 and 0.0197 on seed yield per plant at genotypic and phenotypic levels, respectively. This indicated that, for the genetic analysis of pea, the eleven characters taken under study were sufficient. Path coefficient analysis provides information of direct and indirect effect of any character, whether the observed correlation is due to the direct influence or due to other variables. Based on the above results, the characters like green pod yield per plant, shell weight per plant, number of pods per plant and pod length were the important seed yield determinants. Among these, green pod yield per plant and pod length were positively and significantly correlated with seed yield per plant and also showed direct effect on seed yield per plant. Thus, plant breeders should focus on above mentioned characters during selection of elite genotypes. Based on mean performance the genotypes viz., VRP-383, VRP-311, VRP-320 and Kashi shakti exhibited high values for characters that showed significant positive correlation with seed yield per plant and these genotypes can be further used for the genetic improvement of pea germplasm.

\section{References}

Akinnola A. 2012. Path analysis step by step using excel. Journal of Technical Science and Technologies 1(1): 9-15.

Anant B, Jagdish S, Singh KP and Mathura R. 2006. Plant growth, yield and quality attributes of garden pea as influenced by organic amendments and biofertilizers. Indian Journal of Horticulture 63(3):464466.

Boros L and Wawer A. 2009. Garden pea varietal susceptibility to Mycosphaerella pinodes and its effect on yield components of single plants. Vegetable Crop Research Bulletin 70 (3): 37-47.

Devi PO, Pant SC, Rawat SS, Rana DK and Singh NIK. 2010. Correlation coefficient and genetic divergence analysis in pea. Indian Journal of Horticulture 67(Special Issue): 160-165.

Dewey DR and Lu KH. 1959. A correlation and path coefficient analysis of components of crested wheat grass seed production. Agronomy Journal 52 (3): 515-518.

Dhama SK, Tyagi NK and Singh PB. 2010. Interrelationship and path analysis for seed yield and its component characters under eight environments in pea (Pisum sativum L.). Legume Research 33 (2): 8794.

Duke JA. 1981. Handbook of legumes of world economic importance. Plenum Press. NewYork.

Gul NI, Jilani MS and Kashif W. 2006. Effect of split application of nitrogen levels on the quality and quality parameters of pea (Pisum sativum L.). International Journal of Agriculture and Biology 8 (3): 226230.

Johnson HW, Robinsin HF and Comstock RE. 1955. Genotypic and phenotypic correlation in soyabeans and their implication in selection. Agronomy Journal 47(4): 477-483.

Karnwal MK, Rai R, Singh D, Singh VP, Pal $M$ and Kumar A. 2013. Genetic variability in garden pea under rainfed condition of dry temperate ecosystem. Pantnagar Journal of Research 11(2): 219-224.

Kumar B, Kumar A, Singh AK and Lavanya GR. 2013. Selection strategy for seed yield and maturity in field pea (Pisum sativum L. arvense). Global Journal of Crop, Soil Science and Plant Breeding 1(1): 129-133.

Kumar R, Kumar M, Dogra RK and Bharat NK. 2015. Variability and character 
association studies in garden pea (Pisum sativum L.) during winter season at mid hills of Himachal Pradesh. Legume Research 38:164-168.

Kumar V, Singh J and Srivastava CP. 2014. Genetic variability, correlation and path analysis based on seed yield attributes traits in diverse genotypes of pea (Pisum sativum L.). Journal of Environment and Ecology 32 (2): 1019-1024.

Nandpuri KS, Kumar JC and Singh H. 1973. Heritability and interrelationship of some quantitative chacracters in pea. P.A.U.J. Res. 10: 309-315.

Nawab NN, Subhani GM, Mahmood K, Shakil Q and Saeed A. 2009. Genetic variability, correlation and path analysis studies in garden pea (Pisum sativum L.). Journal of Agricultural Research 46 (4):333-340

NHB， 2018. http://nhb.gov.in/statistics/State _Level/-2017-18(3rd\%20est)\%20$\% 20$ data.pdf

Pal AK and Singh S. 2012. Correlation and path analysis in garden pea (Pisum sativum L. var. hortense). The Asian Journal of Horticulture 7(2): 569-573.

Rai M, Verma A and Vishwanath RK. 2006. Multivariate genetic analysis of pea (Pisum sativum L.). Vegetable Science 33(2):149-154.

Rasaei A, Ghobadi ME, Ghobadi $M$ and Kamiyar AN. 2011. The study of traits correlation and path analysis of the grain yield of the peas in semi-dry conditions in Kermanshah International Conference on Food Engineering and Biotechnology 9: 246-249.

Santalla M, Amurrio JM and De Ron AM. 2001. Food and feed potential breeding value of green, dry and vegetable pea germplasm. Canadian Journal of Plant Science 81 (4): 601-610.

Sharma A, Sood M, Rana A and Singh Y. 2007. Genetic variability and association studies for green pod yield and component horticultural traits in garden pea under high hill dry temperate conditions. Indian Journal of Horticulture 64(4): 410-414.

Sharma MK, Chandel A and Kohli UK. 2009. Genetic evaluation, correlations and path analysis in garden pea (Pisum sativum var. hortense L.). Annals of Horticulture 2(1): 33-38.

Siddika A, Islam AKM, Golam Rasul M, Mian AKM and Ahmed JU. 2013. Genetic Variability in advanced generations of Vegetable Pea (Pisum sativum L.) International Journal of Plant Breeding 7(2):124-128.

Singh A, Singh S and Babu JDP. 2011. Heritability, character association and path analysis studies in early segregating population of field pea (Pisum sativum L. var arvense). International Journal of Plant Breeding and Genetics 5(1): 86-92.

Tiwari G and Lavanya GR. 2012. Genetic variability, character association and component analysis in F4 generation of field pea (Pisum sativum var. arvense L.). Karnataka Journal of Agricultural Science 25(2): 173-175.

Yadav P, Singh AK and Srivastava CP. 2010. Genetic variability and character association in diverse collection of Indian and exotic germplasm lines of Pea (Pisum sativum L.) Vegetable Science 37(1): 7577.

\section{How to cite this article:}

Shalini Singh, B. Singh, V. Rakesh Sharma, Vinay Verma and Mukesh Kumar. 2019. Character Association and Path Analysis in Diverse Genotypes of Pea (Pisum sativum L.). Int.J.Curr.Microbiol.App.Sci. 8(02): 706-713. doi: https://doi.org/10.20546/ijcmas.2019.802.082 